\title{
Mechanical properties of concrete to concrete interfaces under uniaxial and shear forces
}

\author{
Tek eksenli ve kayma yükleri etkisi altında beton-beton arayüzünün \\ mekanik özellikleri
}

\author{
Nihat KABAY1 iD , Ahmet Beșer KIZILKANAT2* ID \\ 1,2Department of Civil Engineering, Faculty of Civil Engineering, Yildiz Technical University, Istanbul, Turkey. \\ nkabay@yildiz.edu.tr, bkkanat@yildiz.edu.tr
}

Received/Geliș Tarihi: 21.07.2017, Accepted/Kabul Tarihi: 10.04.2018

* Corresponding author/Yazışılan Yazar

doi: $10.5505 /$ pajes.2018.72246 Research Article/Araștırma Makalesi

\begin{abstract}
This research aims to evaluate the bond strength between normal strength substrate concrete and different types of high strength overlay concretes. In order to obtain different characteristics in the overlay concrete, silica fume and steel fibers were used. The slant shear and bisurface shear tests were conducted to quantify the effect of different high strength concrete compositions on the bond strength. The mechanical properties of overlay/substrate concrete composites were also analysed on cylindrical samples under uniaxial compression load. The results indicate that the strength of overlay plays an important role on the bond mechanism. The bond strength is found to be dependent on the test mechanism. The test results showed that the bond strength was about 6-12 times higher in slant shear test compared to the bi-surface shear test. The application of parallel model approach on the overlay/substrate concrete composites was found to be quite satisfactory to predict the elastic modulus of the composite.
\end{abstract}

Keywords: Bond strength, Slant shear test, Bi-surface shear test

\begin{abstract}
Öz
Bu deneysel çalıșmada eski betonu temsilen normal dayanımlı beton ile yeni betonu temsil eden farklı tipteki yüksek dayanıml betonlar arasındaki aderans dayanımının incelenmesi amaçlanmıştır. Farklı karakteristiğe sahip yeni beton elde etmek amacı ile silis dumanı ve çelik lif kullanılmıştır. Farklı kompozisyonlara sahip yüksek dayanımlı betonun aderans dayanımına etkisi eğik kayma (slant shear) ve çift yüzey kayma (bi-surface shear) deneyleri ile belirlenmiștir. Ayrıca eski/yeni beton kompozitlerin eksenel basınç yükü etkisi altındaki mekanik özellikleri deneysel olarak belirlenmiștir. Elde edilen sonuçlara göre yeni beton dayanımının ve kayma deneyinde kullanılan yöntemin aderans dayanımı üzerinde önemli bir etkisi olduğu görülmüstür. Eğik kayma deneyinin çift yüzey kayma deneyine göre 6-12 kat yüksek aderans dayanımı verdiği tespit edilmiștir. Paralel model yaklașımının eski/yeni beton kompozitlerin elastisite modülünün tahmininde tatminkar sonuçlar verdiği belirlenmiştir.
\end{abstract}

Anahtar kelimeler: Yapışma dayanımı, Eğik kayma deneyi, Cift yüzey kayma deneyi

\section{Introduction}

Concrete structures, after many years in service, deteriorate due to several factors such as aggressive salts from the environment (i.e. chloride ion penetration, sulphate attack) and loads acting on the structures (i.e. service loads, earthquake loads). Depending on the extent of the degradation repair, strengthening or rebuilding of the existing structure should be considered. Repair and strengthening of concrete involves the removal of the existing concrete layer to ensure a strong bonding, followed by the application of an overlay which could be repair mortars or conventional concrete [1]-[3]. The success of rehabilitation and strengthening process of concrete structures relies on the quality of bonding between the concrete layers and therefore makes it important to assess the bond strength between old (substrate) and new (overlay) concrete [4],[5]. Many factors affect the bond mechanism of interfacial layer between the substrate and the overlay concrete. These factors generally include the compressive strength of the overlay and the substrate concrete, roughness of the substrate concrete surface, curing, and moisture condition of the substrate and the interface [6]-[9].

Bond strength between old and new concrete is a vital factor in repairing and strengthening applications and is still a hot topic in civil engineering [10]. Diab et al. [5] studied the parameters affecting the bonding mechanism between low strength conventional concrete and high strength self-compacting concrete and found that compressive strength of overlay, surface roughness of the substrate concrete and additions to overlay concrete such as latex and fibers significantly affect the bond strength. Beushausen et al. [3] evaluated the effect of moisture level of substrate on the bond strength of substrate concrete/overlay concrete composites and found that prewetting the substrate prior to overlay concrete application had no benefit on the bond strength.

Julio et al. [10] investigated the effect of overlay compressive strength on the bond strength by slant shear test and found that the normal stresses at the interface increased with an increment in the difference between compressive strengths of overlay and substrate concrete and noted that overlay compressive strength might affect the bond strength. The current experimental work aims to research the effect of mechanical properties of substrate concrete and overlay concrete on the bond strength. To reach the aim, bond behaviour at the interface between substrate and overlay concrete is researched by slant shear test and bi-surface shear test. Moreover the mechanical behaviour of cylindrical composites composed of a normal strength substrate concrete covered with 4 different types of high strength overlay concretes (HSC) is also researched. 


\section{Experimental details}

\subsection{Materials and mix design}

CEM I 42.5 R type of ordinary Portland cement (PC) complying with EN 197-1 [11] with specific gravity of 3.15 and Blaine fineness of $326 \mathrm{~m}^{2} / \mathrm{kg}$, was utilized for manufacturing substrate and overlay concretes. Silica fume (SF) was used as a mineral admixture in two of the overlay concrete mixes. The oxide content and the physical properties such as specific gravity and fineness of PC and SF are reported in Table 1. Siliceous sand and calcareous crushed stone sand $\left(D_{\max }=4 \mathrm{~mm}\right)$ were used as fine aggregates, and limestone aggregate ( $D_{\max }=16 \mathrm{~mm}$ ) was used as coarse aggregate in the concrete mixes. The particle density of coarse limestone, siliceous and crushed calcareous aggregates were $2.70,2.56$ and $2.68 \mathrm{~kg} / \mathrm{m}^{3}$ respectively.

Table 1: Oxide content (\%) and physical properties of PC and SF.

\begin{tabular}{ccc}
\hline Material & $\mathrm{PC}$ & $\mathrm{SF}$ \\
\hline $\mathrm{CaO}$ & 61.96 & 1.42 \\
$\mathrm{SiO}_{2}$ & 21.44 & 92.73 \\
$\mathrm{Al}_{2} \mathrm{O}_{3}$ & 5.22 & 1.30 \\
$\mathrm{Fe}_{2} \mathrm{O}_{3}$ & 3.26 & 0.28 \\
$\mathrm{MgO}$ & 1.16 & 0.75 \\
$\mathrm{SO}_{3}$ & 3.04 & 0.19 \\
$\mathrm{LOI}$ & 1.32 & 1.44 \\
Specific gravity & 3.14 & 2.32 \\
Fineness (Blaine, $\left.{ }^{2} / \mathrm{kg}\right)$ & 365 & 21000 \\
\hline
\end{tabular}

Polycarboxylic ether based chemical admixture with density of $1.10 \mathrm{~g} / \mathrm{cm}^{3}$ was used to obtain a slump value of $7 \pm 2 \mathrm{~cm}$. The amount of superplasticizer was regulated at the time of mixing to obtain the specified slump.

A single type steel fiber was used for the production of fiber reinforced concretes. The properties of the steel fiber obtained from the manufacturer are presented in Table 2.

Table 2: Properties of steel fiber.

\begin{tabular}{ccccc}
\hline Shape & $\begin{array}{c}\text { Diameter } \\
(\mu \mathrm{m})\end{array}$ & $\begin{array}{c}\text { Length } \\
(\mathrm{mm})\end{array}$ & $\begin{array}{c}\text { Tensile } \\
\text { strength } \\
(\mathrm{MPa})\end{array}$ & $\begin{array}{c}\text { MOE } \\
(\mathrm{GPa})\end{array}$ \\
\hline Straight & 150 & 13 & 3000 & 200 \\
\hline
\end{tabular}

In this study, a total of 4 different high strength overlay concretes (NC, SFC, FRC and FRSFC) and 1 normal strength substrate concrete (SC) were prepared and coded as shown in Table 3. A concrete mixer with a vertical rotation axis was used for concrete production and the properties of concrete in fresh state were determined after complete the mixing and the results are presented in Table 4 along with the mix design.

\section{$2.1 \quad$ Curing and testing procedure}

In order to determine the mechanical properties such as modulus of elasticity (MOE), compressive strength and splitting tensile strength, all types of concretes were cast in standard $\emptyset 150 / 300 \mathrm{~mm}$ and $\varnothing 100 / 200 \mathrm{~mm}$ cylinder moulds, demoulded at $24 \mathrm{~h}$ and kept in the storage room at $20 \pm 2{ }^{\circ} \mathrm{C}$ and relative humidity of $65 \pm 5 \%$ for 27 days. Compressive and splitting tensile strength tests were performed in agreement with EN 12390-3 [12] and ASTM C496 [13] respectively. Cylindrical specimens with dimensions of $\emptyset 150 / 300 \mathrm{~mm}$ were used to determine the static MOE as explained in ASTM C469 [14] using the stress-strain data, as given by Eq. (1).

$$
E=\frac{\left(S_{2}-S_{1}\right)}{\left(\varepsilon_{2}-0.00005\right)}
$$

where $E$ represents the MOE, $S_{1}$ is the stress corresponding to a longitudinal strain, $\varepsilon_{1}$, of $50 \mu \mathrm{m}, S_{2}$ is the stress corresponding to $40 \%$ of the maximum load and $\varepsilon_{2}$ is the strain produced by stress $S_{2}$. The longitudinal displacements was gauged with two linear variable differential transformers (LVDTs) on each specimen. For each mixture, the average value of the three specimens is reported here. The following steps were adopted to attain a proper stress-strain curve, [15]. The strain was considered to increase in $0.00001 \mathrm{~mm} / \mathrm{mm}$ increments. The stresses corresponding to each strain data points were determined using the linear interpolation method.

Table 3: Definition of mixture codes.

\begin{tabular}{cc}
\hline Code & Definition \\
\hline SC & Substrate concrete \\
NC & Plain HSC \\
SFC & SF added HSC \\
FRC & Fiber added HSC \\
FRSFC & SF and fiber added HSC \\
\hline SC + NC & \\
SC + SFC & Composite samples composed of \\
SC + FRC & substrate concrete and different types \\
SC + FRSFC & of overlay concretes \\
\hline
\end{tabular}

Bond strength was determined by slant shear and bi-surface shear tests on cylindrical and cubic specimens respectively. The substrate concrete was initially placed into moulds, and a setting retarder was sprayed on the fresh concrete surfaces. The concretes were demoulded after 24 hours and the bond surfaces were roughened by using a stiff steel brush. The attention was paid to obtain similar roughness on the substrate surface to discard the effect of this parameter on the bond strength. The specimens were then kept under water for 5 days and air dried in the storage room for $24 \mathrm{~h}$ before the new concrete overlays were applied. The moisture condition of the substrate before casting the overlay concretes was dry. Prior to placing the overlays, the contact face of concretes was cleaned applying wire brush and high pressure air and the substrate concrete specimens were then returned to the moulds. Each empty part of the mould was filled with the overlay concretes. The overlay concretes were compacted with a steel bar and by tapping the mould sides with a plastic mallet.

The slant shear test was carried out as per ASTM C882/C882M12 [16] on composite cylinders of $150 \mathrm{~mm}$ diameter and 300 $\mathrm{mm}$ height (Figure 1). In slant shear test, the overlay concrete is bonded to the substrate concrete on a slant elliptical plane inclined at an angle of $30^{\circ}$ from the vertical axis (loading axis).
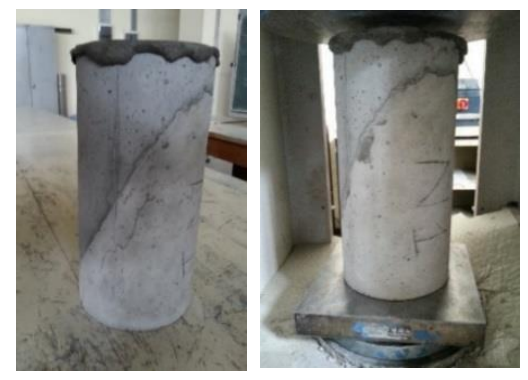

Figure 1: Specimens for slant shear test. 
Table 4: Mixture design $\left(\mathrm{kg} / \mathrm{m}^{3}\right)$ and fresh state properties of concretes.

\begin{tabular}{ccccccccccc}
\hline Mix code & Cement & Water & River sand & $\begin{array}{c}\text { Crushed } \\
\text { sand }\end{array}$ & $\begin{array}{c}\text { Limestone } \\
\text { coarse }\end{array}$ & $\begin{array}{c}\text { Silica } \\
\text { fume }\end{array}$ & $\begin{array}{c}\text { Steel } \\
\text { fiber }\end{array}$ & $\begin{array}{c}\text { Super } \\
\text { plasticizer }\end{array}$ & $\begin{array}{c}\text { Slump } \\
\text { (cm) }\end{array}$ & $\begin{array}{c}\text { Fresh } \\
\text { density }\end{array}$ \\
\hline SC & 230 & 161 & 490 & 719 & 829 & -- & -- & 2.3 & 5 & 2422 \\
NC & 350 & 157.5 & 468 & 686 & 791 & -- & -- & 4.6 & 6 & 2462 \\
SFC & 315 & 157.5 & 485 & 711 & 820 & 35 & -- & 5.3 & 9 & 2459 \\
FRC & 350 & 157.5 & 464 & 681 & 786 & -- & 39 & 7.0 & 5 & 2503 \\
FRSFC & 315 & 157.5 & 461 & 677 & 780 & 35 & 39 & 7.7 & 7 & 2501 \\
\hline
\end{tabular}

The bi-surface shear test was carried out on $150 \mathrm{~mm}$ cubic specimens where the substrate concrete layer and the overlay concrete layer account for two-thirds and one third of the volume of the specimen (Figure 2), respectively. The composite specimens are tested under compression using three steel plates, with $50 \times 150 \times 25 \mathrm{~mm}^{3}$, originating two shear planes where one shear plane corresponds to the bonded interface, and the second plane is located in the substrate concrete. The specimen shape and proportions are illustrated in Figure 3 for slant shear and bi-surface shear tests.
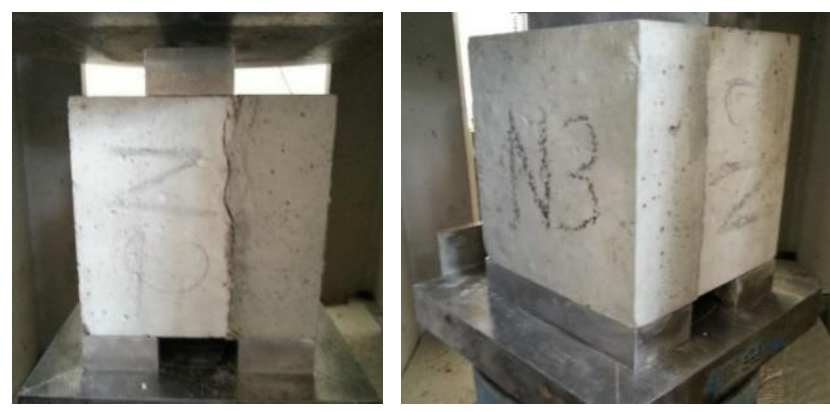

Figure 2: Specimens for bi-surface shear test.

The behaviour of composite specimens under uniaxial loading was also researched by covering a specific volume of substrate concrete by the overlay concrete as shown in Figure 4 and Figure 5. Initially, substrate samples were cast in $75 \times 300 \mathrm{~mm}$ (diameter $x$ height) cylinder moulds. Samples were demoulded 24 hours after casting and the lateral surfaces of the samples were roughened the same way as in the shear test samples. The test specimens were then immersed in water for 5 days and kept in the storage room for 1 day.
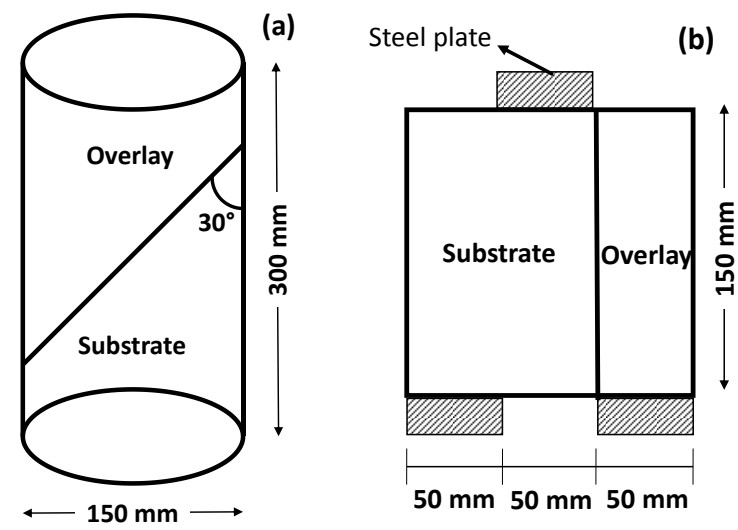

Figure 3: Specimen geometry and dimensions for.

(a): Slant shear, (b): Bi-surface shear.
The substrate cylinders of $\varnothing 75 / 300 \mathrm{~mm}$ were placed in the middle of standard $\emptyset 150 / 300 \mathrm{~mm}$ moulds and the overlay concrete was cast around it. The composite samples were demoulded after $24 \mathrm{~h}$ and cured in the storage room for another 27 days.

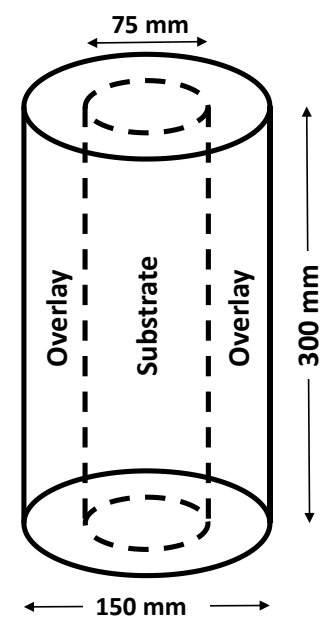

Figure 4: Scheme of composite specimen composed of substrate and overlay.

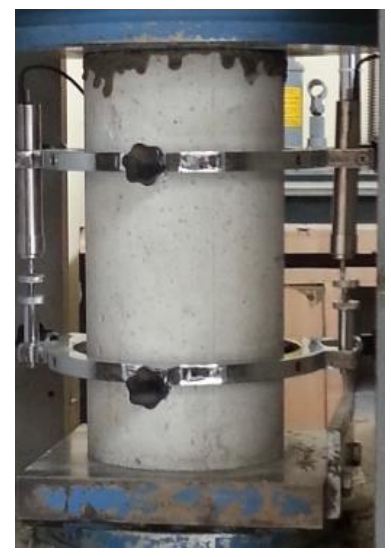

Figure 5: Composite specimens tested under uniaxial loading.

\section{Results and discussion}

\subsection{Mechanical properties of concrete mixes}

Table 5 presents the average compressive strength, MOE and splitting tensile strength values of concrete series. Compressive strength of the substrate concrete was, as expected, the lowest as $39 \mathrm{MPa}$. The overlay concretes had higher strength values compared to that of the substrate concrete and the strength values varied between 60.8 and $76.9 \mathrm{MPa}$. The addition of SF, steel fiber, and SF and fiber together resulted in higher 
compressive strength as shown in Table 5. The MOE of concrete mixes followed a similar fashion as in compressive strength and varied between $34813 \mathrm{MPa}$ and $42355 \mathrm{MPa}$. Splitting tensile strength of the substrate concrete was $3.64 \mathrm{MPa}$ and varied between 4.69 and $6.14 \mathrm{MPa}$ for the overlay concretes. The inclusion of steel fiber improved the tensile strength by $17 \%$ and the addition of SF and fiber together resulted in an enhancement of $31 \%$ compared to NC mix. The partial utilization of SF by cement resulted in denser and improved microstructure which affected the strength characteristics of concrete as clearly seen in Table 5.

Table 5: Mechanical properties of concrete series.

\begin{tabular}{ccccc}
\hline $\begin{array}{c}\text { Concrete } \\
\text { Layer }\end{array}$ & $\begin{array}{c}\text { Mix } \\
\text { code }\end{array}$ & $\begin{array}{c}\text { Compressive } \\
\text { strength } \\
\text { (MPa) }\end{array}$ & $\begin{array}{c}\text { MOE } \\
(\mathrm{MPa})\end{array}$ & $\begin{array}{c}\text { Splitting } \\
\text { tensile } \\
\text { strength } \\
\text { (MPa) }\end{array}$ \\
\hline Substrate & SC & 39.0 & 34813 & 3.64 \\
\hline \multirow{5}{*}{ Overlay } & NC & 60.8 & 38276 & 4.69 \\
& SFC & 70.3 & 42355 & 4.78 \\
& FRC & 62.6 & 35748 & 5.48 \\
& FRSFC & 76.9 & 39490 & 6.14 \\
\hline
\end{tabular}

\subsection{Mechanical properties of composites composed of} substrate and overlay concretes

Figure 6-9 shows the compressive strength, MOE and the stress-strain curves of concrete mixes and the composites (cylindrical samples composed of overlay and substrate concretes) respectively. It is clear from the Figure 6 that the compressive strength of composite mixes possessed higher strength values than the substrate concrete but failed to reach or exceed the strength of overlay concretes. A similar trend was also noticed on the MOE of composite mixes, plotted in Figure 7. Based on the compression test result carried out on both plain and composite test specimens. It was observed that the strength loss generally increased with an increase in overlay concrete which verifies the influence of the rigidity difference of concrete layers. The highest strength loss was noticed in SC+FRSFC composite mix as $26 \%$ while the lowest loss was observed in $\mathrm{SC}+\mathrm{NC}$ composites as $9 \%$ compared to FRSFC and $\mathrm{NC}$ mixes respectively.

The usage of steel fibers resulted in an increment of strain corresponding to the peak stress (Figure 7). Especially the FRSFC has remarkably higher strain capacity than other mixes. However, the remarkable effect of fiber addition on the stressstrain behaviour of composites was noticed in the FRC confined composites. The results show that stress-strain behaviour of substrate concrete has changed significantly when confined with new concrete (Figure 8). The FRC confined SC composite is more ductile than both SC and FRC when subjected to uniaxial stress. The significant effect of FRC can be seen obviously in the post peak, descending part of the curve. The toughness of the SC+FRC composite, the area under the stress-strain curve, is greater than other composite series. In any cases debonding or shear failure was not observed. The failure can be characterized as vertical cracks and it can be said that the ultimate strength of overlay concrete was major parameter that governs the compressive strength of composite.

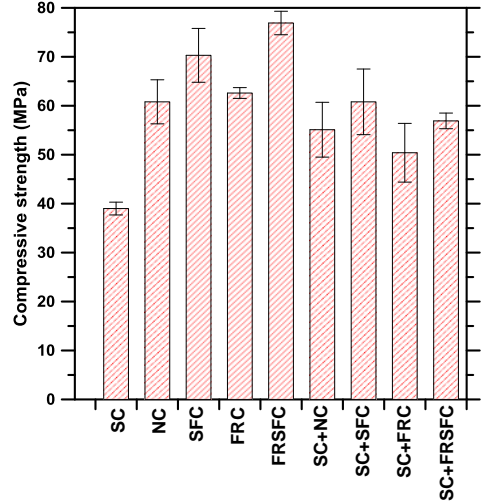

Figure 6: Compressive strength of concrete mixes and composites.

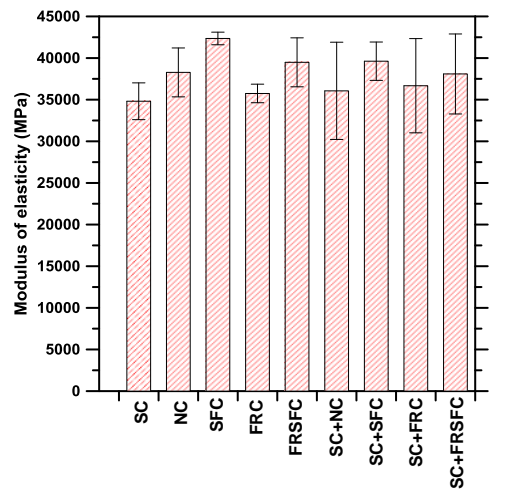

Figure 7: MOE of concrete mixes and the composites.

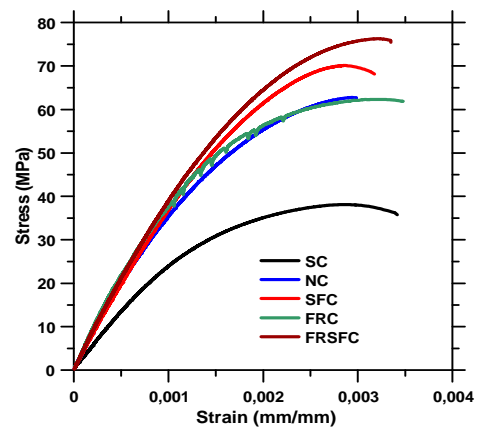

Figure 8: Stress-strain curves of concrete mixes under uniaxial loading.

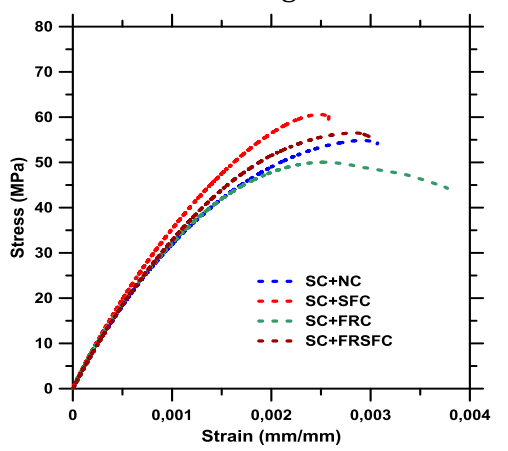

Figure 9: Stress-strain curves of composites under uniaxial loading.

Application of parallel model (Eq. (2)) approach [17] was found to be quite satisfactory to estimate the MOE of composite concrete members (Figure 10). 


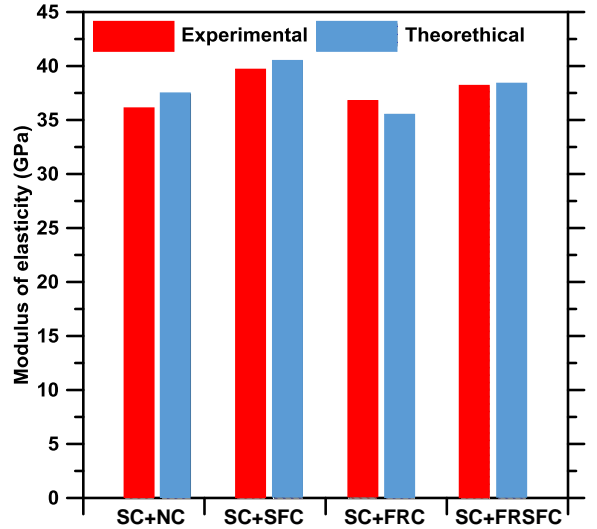

Figure 10: Experimental and theoretical results of MOE of composites.

The composite concrete was assumed to be composed of two phases (substrate and overlay concrete), where the volume of substrate concrete corresponds to $25 \%$ and the volume of overlay concrete corresponds to $75 \%$ of the total composite volume.

$$
E_{c}=E_{1} V_{1}+E_{2} V_{2}
$$

In Eq. (2), $E_{c}, E_{1}$ and $E_{2}$ are the MOE of composite, substrate concrete and overlay concrete, respectively; and $V_{1}$ and $V_{2}$ are the volume fractions of substrate and overlay concrete.

\subsection{Shear test}

Shear test results are depicted in Figure 11. The results indicate that the increase in the overlay concrete strength also improved the bond strength of concretes, similar results are reported by other researchers [3],[5],[10],[18]. Although SF incorporation was dramatically increased the bond strength calculated from in bi-surface shear test, the same performance of SF was not notable when the slant shear test results were considered. However, the highest improvement in the bond strength was observed on SC+FRSFC samples where SF and steel fibers were introduced in the overlay concrete. The effect of overlay concrete properties on the bond strength was more clearly noticed in the bi-surface shear test; as the overlay concrete compressive strength increased the shear strength increased up to about 2 times the SC+NC mix. The bi-surface shear strength varied between a broader ranges of 1.3-2.9 $\mathrm{MPa}$ compared to the slant shear strength. The slant shear strength was found to be between a narrow ranges of 15.8-16.8 MPa, but an increasing trend with an increment in the overlay compressive strength can be noticed in Figure 12.

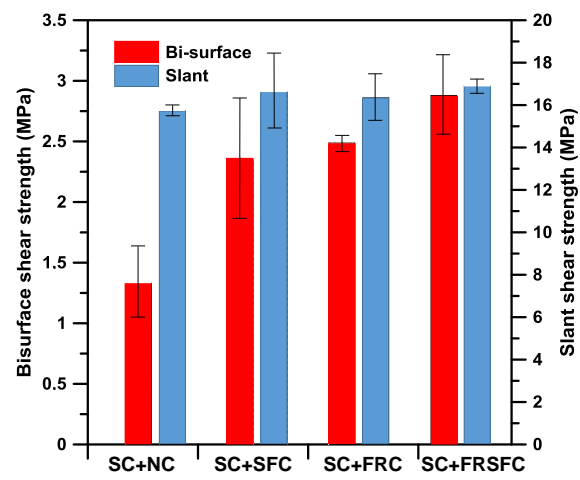

Figure 11: Shear test results.

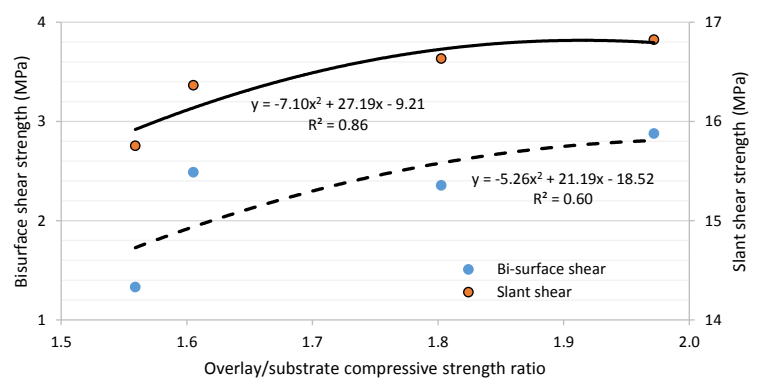

Figure 12: The relation between bond strength and overlay/substrate compressive strength ratio.

Test results also reveal that the value of bond strength depends on the test method. The slant shear test results were found to be 6 to 12 times higher than the bi-surface shear test results. As explained by Momazey et al. [4], higher compressive stresses occur in slant shear test which develop extra friction forces between the substrate and overlay interface which consequently increase the ultimate shear load.

The specimens were visually observed in detail to identify the crack formations and failure modes after the shear tests. Three failure modes were identified as shown in Table 6 . The concrete specimens failed due to the

i. Interface failure (IF),

ii. Interface+substrate failure (ISF), and

iii. Mixed failure (combined failure of interface, substrate and overlay).

Table 6: Failure modes of concrete mixes after shear test.

\begin{tabular}{cccc}
\hline \multirow{2}{*}{ Mix code } & \multirow{2}{*}{ Sample \# } & \multicolumn{2}{c}{ Failure Mode } \\
\cline { 2 - 4 } SC/NC & 1 & Bi-shear & Slant shear \\
& 2 & IF & Mixed \\
& 3 & IF & Mixed \\
\hline \multirow{3}{*}{ SC/SFC } & 1 & ISF & Mixed \\
& 2 & IF & IF \\
& 3 & IF & IF \\
SC/FRC & 1 & IF & IF \\
& 2 & ISF & IF \\
\hline \multirow{3}{*}{ SC/FRSFC } & 3 & IF & IF \\
& 1 & IF & IF \\
& 3 & IF & IF \\
\hline
\end{tabular}

The most governing failure mode in bi-shear test was the interface failure (Figure 13a). On the other hand, in some samples of SC+SFC and SC+FRC mixes, the failure occurred both at the interface and at the substrate as shown in Figure $13 \mathrm{~b}$ (Note that the cracks are highlighted).

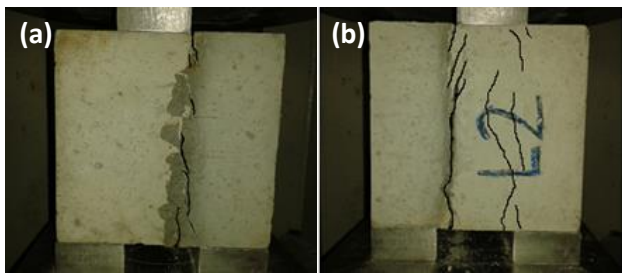

Figure 13: Failure modes in bi-shear test. (a): Interface failure, (b): Interface + substrate failure. 
In slant shear test two distinctive failure modes were seen; interface failure (Figure 14a) and mixed failure (Figure 14b).

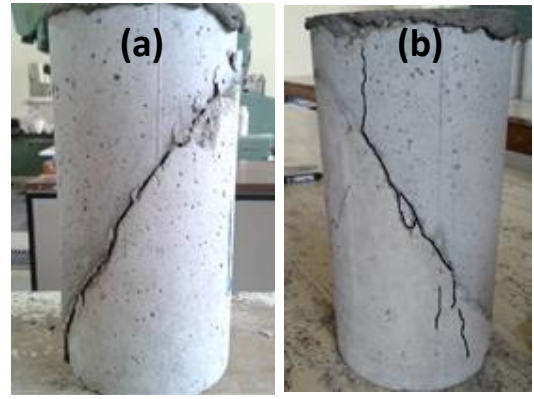

Figure 14: Failure modes in slant shear test. (a): Interface failure, (b): Mixed failure.

\section{Conclusions}

This research experimentally investigates the bond strength between normal strength substrate concrete and different types of high strength overlay concretes by two different shear test methods. Mechanical properties of composite concretes composed of overlay and substrate concretes were also analysed on cylindrical samples under uniaxial compression load. According to the test results, the conclusions are summarized as follows:

- Test results on the composites revealed that the compressive strength and MOE of composite mixes possessed higher values than the substrate concrete but failed to reach or exceed the overlay concretes. The application of parallel model approach was found to be quite satisfactory to estimate the MOE of composite concretes,

- The increase in the overlay concrete strength improved the bond strength of concretes. The highest improvement in the bond strength was observed on SC+FRSFC samples where SF and steel fiber were introduced together in the overlay concrete,

- The effect of overlay concrete properties on the bond strength was more clearly noticed in the bi-surface shear test, as the overlay concrete compressive strength raised the shear strength about 2 times compared to the $\mathrm{SC}+\mathrm{NC}$ mix.,

- $\quad$ The slant shear strength was found to be between a narrow ranges of 15.8-16.8 $\mathrm{MPa}$, but followed a rising trend with an increment in the overlay compressive strength,

- The bond strength value is found to be highly dependent on the test method. The slant shear test results were about 6-12 times higher than the bisurface shear test results,

- $\quad$ The most governing failure mode in bi-shear test was the interface failure (bond failure). On the other hand, in slant shear test two distinctive failure modes were observed; interface failure and mixed failure.

\section{References}

[1] Indrajit R, Julio FD, Shiwei L. "Interface evaluations of overlay-concrete bi-layer composites by a direct shear test method". Cement and Concrete Composites, 27(3), 339-347, 2005.
[2] Espeche A, Léon J. "Estimation of bond strength envelopes for old-to-new concrete interfaces based on a cylinder splitting test". Construction and Building Materials, 25(3), 1222-1235, 2011.

[3] Beushausen H, Höhlig B, Talotti M. "The influence of substrate moisture preparation on bond strength of concrete overlays and the microstructure of the OTZ". Cement and Concrete Research, 92, 84-91, 2017.

[4] Momayeza A, Ehsanib MR, Ramezanianpoura AA, Rajaiea H. "Comparison of methods for evaluating bond strength between concrete substrate and repair materials". Cement and Concrete Research, 35(4), 748-757, 2005.

[5] Diab AM, Elmoaty M, Eldin MRT. "Slant shear bond strength between self-compacting concrete and old concrete". Construction and Building Materials, 130, 73-82, 2017.

[6] Saldanha R, Eduardo J, Danial C, Pedro S. "A modified slant shear test designed to enforce adhesive failure". Construction and Building Materials, 41, 673-680, 2013.

[7] Eduardo J, Branco F, Silva V. "Concrete-to- concrete bond strength. Influence of the substrate surface". Construction and Building Materials, 18(9), 675-681, 2004.

[8] Pedro S, Eduardo J. "Factors affecting bond strength between new and old concrete". ACI Materials Journal, 108(4), 449-456, 2011.

[9] Rith M, Kim YK, Lee SW, Park JY, Han SH. "Analysis of in situ bond strength of bonded concrete overlay". Construction and Building Materials, 111, 111-118, 2016.

[10] Júlioa ENBS, Branco FAB, Silvac VD, Lourenço JF. "Influence of added concrete compressive strength on adhesion to an existing concrete substrate". Building and Environment, 41, 1934-1939, 2006.

[11] European Committee for Standardization. "Cement. Composition, specifications and conformity criteria for common cements". Brussels, Belgium, EN 197-1, 2011.

[12] European Committee for Standardization. "Testing Hardened Concrete. Compressive Strength of Test Specimens". Brussels, Belgium, EN 12390-3, 2009.

[13] American Society for Testing and Materials. "Standard Test Method for Splitting Tensile Strength of Cylindrical Concrete Specimens". West Conshohocken, PA, USA, ASTM C496, 2011.

[14] American Society for Testing and Materials. "Standard Test Method for Static Modulus of Elasticity and Poisson's Ratio of Concrete in Compression". West Conshohocken, PA, USA, ASTM C469, 2014.

[15] Kizilkanat AB, Kabay N, Akyüncü V, Chowdhury S, Akça AH. "Mechanical properties and fracture behavior of basalt and glass fiber reinforced concrete: An experimental study". Construction and Building Materials, 100, 218-224, 2015.

[16] American Society for Testing and Materials. "Standard Test Method for Bond Strength of Epoxy-Resin Systems Used with Concrete by Slant Shear". West Conshohocken, PA, USA, ASTM C882, 2013.

[17] Brandt AM. Cement-Based Composites Second Edition Materials, Mechanical Properties and Performance. Taylor \& Francis, 2009.

[18] Sahmaran M, Yücel HE, Yildirim G, Al-Emam M, Lachemi M. "Investigation of the Bond between Concrete Substrate and ECC Overlays". Journal of Materials in Civil Engineering, 26(1), 167-174, 2014. 